\title{
Predictive model of water stress in Tenera oil palm by means of spectral signature methods
}

\author{
Angie Marcela Galvez-Valencia ${ }^{1}$, Yeison Alberto Garcés-Gómez ${ }^{2}$, Erwin Leandro Lemus Rodríguez ${ }^{3}$, \\ Miguel Andrés Arango Argoti ${ }^{4}$ \\ ${ }^{1,3}$ Manuelita Aceites y Energía, Aceites Manuelita S.A., Colombia \\ ${ }^{2}$ Universidad Católica de Manizales, Unidad Académica de Formación en Ciencias Naturales y Matemáticas, Colombia \\ ${ }^{4}$ Corporación Colombiana de Investigación Agropecuaria-AGROSAVIA, Colombia
}

\section{Article Info}

Article history:

Received Aug 10, 2020

Revised Jan 8, 2021

Accepted Jan 19, 2021

\section{Keywords:}

Predictive model

Remote sensing

Spectral signature

Tenera oil palm

Water stress

\begin{abstract}
Agriculture as a competitive business, seeks to improve productivity within crops with a more sustainable environmental management. It is important that agriculture includes new technologies that allow it to generate differential, precise and real-time information. In Colombia, the current lack of knowledge about techniques that allow early identification of water stress in African palm could generate a loss in the investment made in the fertilization of the crop, cause an increase in diseases, pests, and susceptibility to compaction or abortions in female flowers that would lead to decreases in production. In this work, a predictive model is established to quantify water stress based on spectral, physiological and soil information in African palm plants. To this end, a study was carried out in an oil palm plantation where treatments were established with 3 ranges of humidity. It was found that the indices with the highest correlation with the biophysical variable soil moisture were: NDVI_1 and NDVI_16 for treatment 1, SR_4 for treatment 2 and NDVI_16 and NDVI_20 for treatment 3. Finally, the third order polynomial regression model that obtained higher correlation coefficients of Pearson $\mathrm{R}^{\wedge} 2=0.73$ was selected as the most suitable model to estimate soil moisture content for treatments 2 and 3.
\end{abstract}

This is an open access article under the CC BY-SA license.

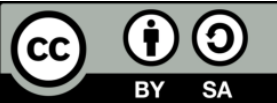

\section{Corresponding Author:}

Yeison Alberto Garcés-Gómez

Unidad Académica de Formación en Ciencias Naturales y Matemáticas

Universidad Católica de Manizales

Cra 23 No 60 - 63, Manizales, Caldas, Colombia

Email: ygarces@ucm.edu.co

\section{INTRODUCTION}

Climate variability has made it difficult to analyse weather conditions that are indispensable for planning in agriculture. Currently, this planning of agricultural activities varies constantly according to the study of the climatic events that occur day by day. Therefore, it is essential to develop tools that allow a quick analysis of the information and that are available to the farmers [1-5].

In Colombia, many organizations from different sectors have advanced in the consolidation of these tools. However, in the case of oil palm, the current information is insufficient, which does not allow most palm growers to plan their activities better $[6,7]$. In this aspect the use of satellite images allows an important development in many aspects of humanity. In the field of agriculture it is presented as a low-cost and highly applicable tool for the improvement of conditions or productivity rates that can help in the development and quality of food security [8-10]. 
The oil palm is considered worldwide the most productive oil plant in terms of oil per hectare. The world production of vegetable oils and fats is around 227 million tons of oil per year, with palm oil and palm kernel oil accounting for $35 \%$ of this total. Asia produces $88 \%$ of the world's palm oil. Colombia is the fourth in the world with about 1,700 million tons per year and first in America with $2.4 \%$ of the total tons of palm oil [11-14].

The average oil palm yield ranges from 4 to 6 tons of oil per hectare per year, this level of yield is 7 to 10 times higher than other oil crops such as Soya, Rapeseed, Sunflower which are grown in temperate and tropical countries. For the moment the only means of producing oil per hectare higher than the cultivation of palm are the micro algae crops, however, this technology is expensive and very advanced technical management and specialized that is not available to all farmers and producers $[15,16]$. In Colombia, this crop is established in 540 thousand hectares in 21 departments and 161 municipalities where $83 \%$ of the producers are small farmers [12].

\section{WATER STRESS AND SPECTRAL INDICES}

The palm transpires 5-6 mm of water per day during the year. In areas with low rainfall that do not allow this water intake, it can generate stress and compromise the physiological functions in the palm tissue. The palm adapts to periods of drought by closing its stomata, opening its leaves late and producing fewer bunches. In addition, these prolonged conditions can generate decreases in the sex ratio, which leads to decreased yields 19-22 months later and the abortion of female flowers. Another stress condition is generated by excessive humidity where the soil presents anaerobic conditions. This generates deterioration in the development of the superficial root system of the palm which presents symptoms of nitrogen deficiency [17-19].

Currently the calculation of water content in vegetation is done by traditional methods such as leaf water content or direct field methods. "In crops established in large areas, monitoring of this variable is costly because there are not enough staff and tools or they have a high economic value" [20]. The spectral methods used in other crops are tools that propose more precise and fast measurement methodologies. One of the traditional methods for calculating water content in vegetation directly used by authors such as [20, 21], is the calculation of the water content in the leaf (RWC) and the equivalent water thickness (EWT), and then correlates with spectral indices.

Spectral indices are based on the combination of band pairs and their use in the field of remote sensing has been in place since the beginning of the incursion of these technologies. Their objective has been to indirectly calculate biophysical variables of the vegetation. In the study conducted by [22] evaluates the potential of an airborne sensor with a range of 360 to $1050 \mathrm{~nm}$, to estimate the moisture content of a pasture area. The study was conducted by Samuel, O. in 2019 at McGill University, Ste Anne de Bellevue, Quebec, Canada. He investigated the potential of using reflectance indices to detect water stress in a pepper crop under glass. In [23] an experiment was carried out with two species of vegetation (cork oak ( $Q$. suber) and sessile oak ( $Q$. robur)) in order to estimate the moisture content using spectral data. On the other hand in $[24,25]$, a study was conducted in the greenhouse on the McDonald campus of McGill University, Ste Anne De Bellevue, Quebec, Canada. To evaluate the feasibility of using indices derived from hyper spectral sensors to identify water stress in tomato plants (Solanum Lycopersicum L).

\section{RESEARCH METHOD}

The methodological scheme has been developed in Figure 1. The first phase corresponds to the collection of data in the plantation, these data were of two types, biophysical (soil moisture, leaf water content, chlorophyll and bulb temperature) and absorption of the spectral signatures (ASS). With the previous data, the correlations were analyzed to determine the indexes with higher values.

In the second phase, the analysis of the spectral indices from the ASS analysis and the correlation between spectral signatures was carried out to select the ranges that would provide more information. The final phase consisted of making correlations between the humidity and the spectral ranges determined in the previous phase, later the ranges with more representative correlations were selected with respect to the humidity of the soil and these allowed the generation of the predictive model. The study area is located in the plantation "Manuelita Aceites y Energia", "San Carlos de Guaroa", Colombia. Plantation located in the central western part of the department of Meta as shown in Figure 2. 


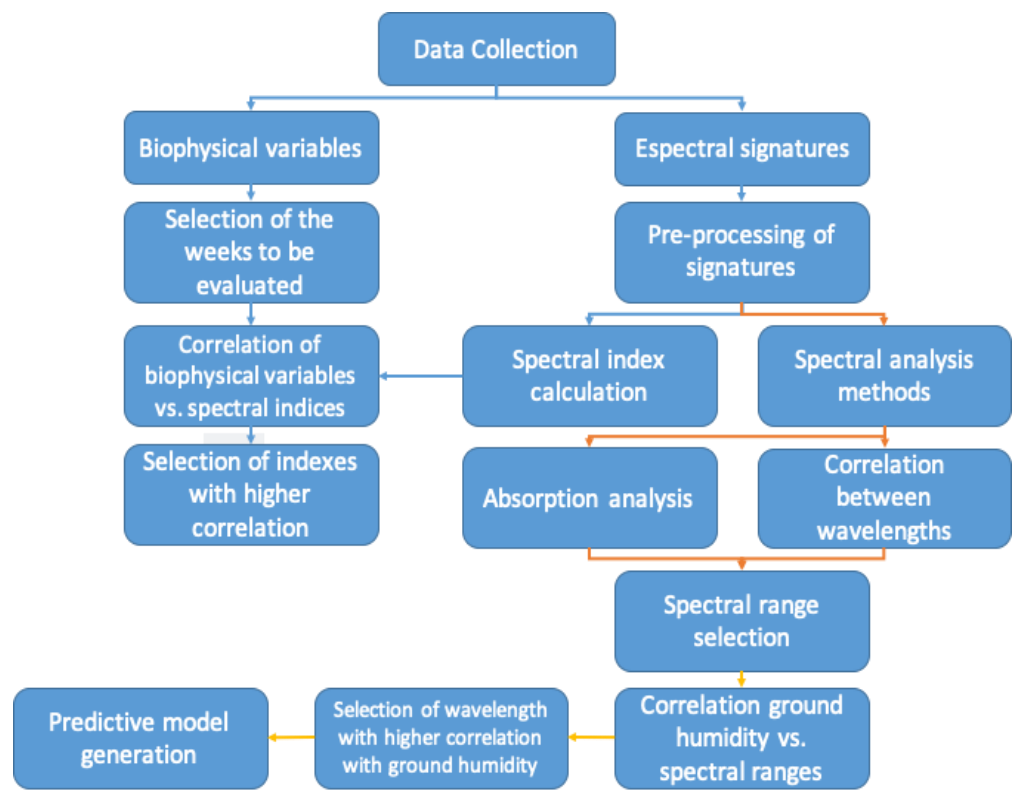

Figure 1. Methodological scheme
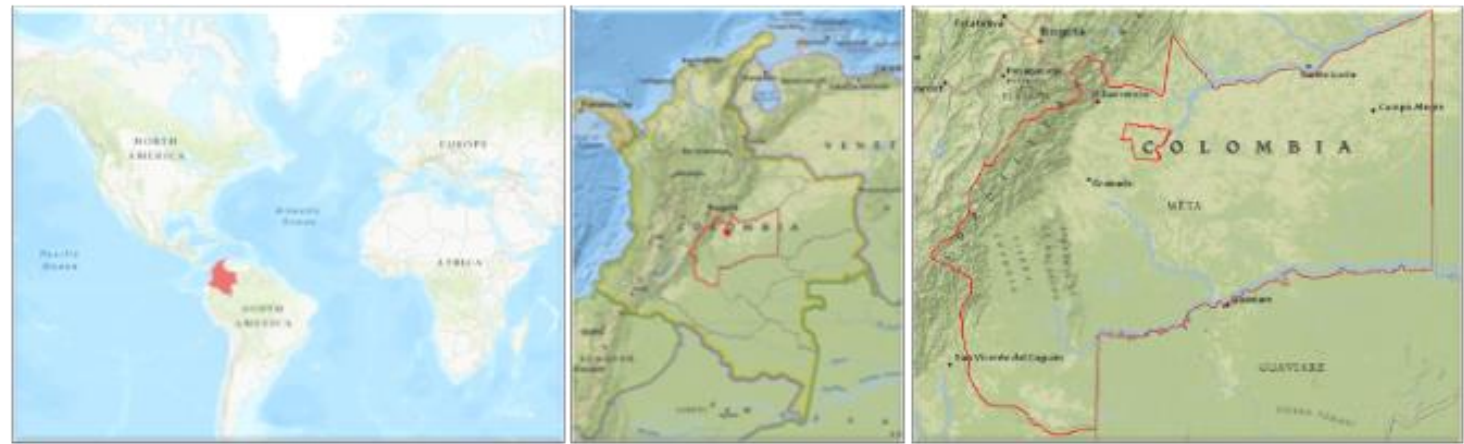

Figure 2. Location of the study area

\subsection{Description of the experimental parcel}

The greenhouse measures $15 \times 15 \mathrm{~m}$, covered with 8-gauge plastic that allows $95 \%$ of light transmission. The experimental plot had a group of palms of the Tenera variety, with 10 months of age, which were arranged at a distance of 1 meter in an equilateral triangle as shown in Figure 3 . Prior to selection, a qualitative census and evaluation of the palms to be studied is carried out, discarding those that do not present homogeneous physiological development conditions for the selected experimental group. The drip system consisted of pressure-compensating emitters, with a discharge of $1.2 \mathrm{~L}$ per day, calibrated flows in the nursery. The amount of water applied was calculated based on the requirement established from tests carried out previously in the greenhouse to ensure moisture at field capacity. Irrigation was applied uniformly to all treatments prior to the start of the experiment for two weeks at the established fertilizer rates. In the $34^{\text {th }}$ week the water and fertilization irrigation was stopped and three types of treatments were installed with only water variation. The treatments were ordered as: Treatment 1-Humidity saturation (Line 1, 2 and 3): For these lines, additional drippers were installed, ensuring humidity above the field capacity. Saturation was maintained throughout the experiment. Treatment 2-Water deficiency (Line 4, 5 and 6): For this treatment the initially installed drippers were removed. Treatment without irrigation. Treatment 3-Field capacity (Line 7, 8 and 9): For this treatment the initially installed flow rate was left, which according to studies carried out by the company corresponds to the flow rate to keep the palms at field capacity.

Data collection was done the first three days of each week, measuring one line per treatment each day and completing all lines in one week. Field data was collected for 10 weeks. Moisture readings were taken using a hardened sensor, which was calibrated with gravimetric soil moisture measurements. The 
relative water content of the leaf was measured by selecting the youngest fully expanded leaves, third leaf from the top. These leaflets were collected in sealed plastic bags which were quickly transported (time not exceeding one hour) to the laboratory for measurements to avoid moisture loss. A central square of the leaflet, approximately $10 \mathrm{~cm}$ wide, was selected. The fresh weight was recorded on an analytical balance. Finally they were dried in an oven until a constant weight was achieved and then weighed again. The reflectance was measured using an Ocean Optics USB-650 tide network spectrometer, which measures the reflectance between 350 and $1000 \mathrm{~nm}$ with a spectral resolution of $2.0 \mathrm{~nm}$. The sensor was calibrated for each reading. Three measurements were made in different observation directions trying to keep the optic fiber at $45^{\circ}$ at a distance of approximately $10 \mathrm{~cm}$. The chlorophyll content was measured using a SPAD-502 sensor which determines the relative amount of chlorophyll present by measuring leaf absorption in two wavelength regions in the red and infrared regions.

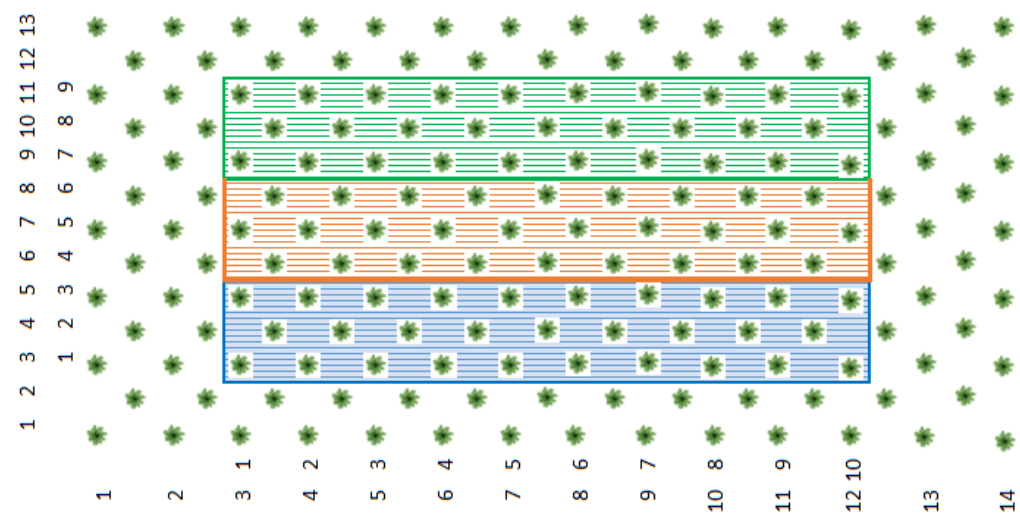

Figure 3. Distribution of the experimental parcel; Treatment 1-Humidity saturation (Line 1, 2 and 3 in blue), Treatment 2-Water Deficiency (Line 4, 5 and 6 in red), Treatment 3-Ideal humidity condition of the crop called field capacity (Line 7, 8 and 9 in green)

\section{RESULTS AND DISCUSSION}

The first part of the analysis was to study the collected moisture data to statistically determine from which week significant differences were found. Figure 4 illustrates the average moisture readings for each week. The statistical analysis shows that significant differences are found as of week 8 with ANOVA and Tukey's comparison rejecting the null hypothesis of equality with a p-value $<0.05$.

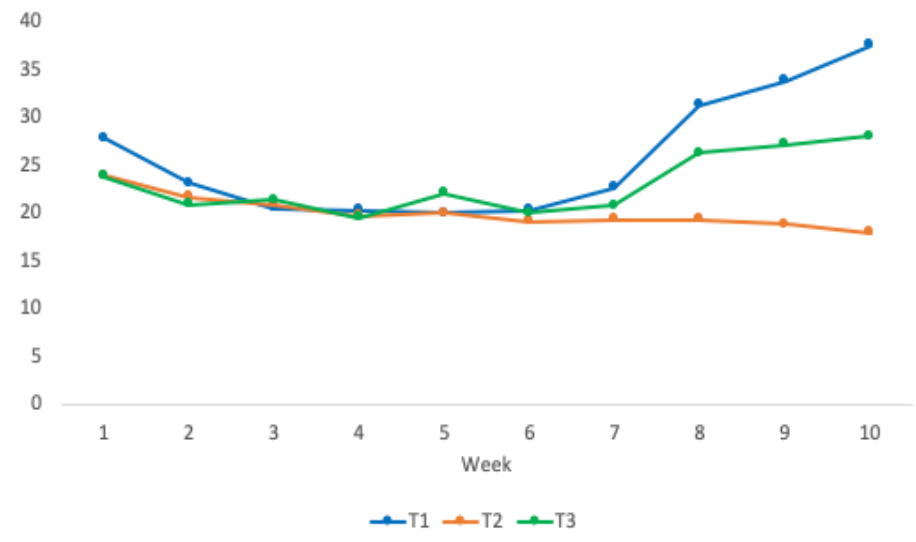

Figure 4. Ground humidity vs. measured weeks

\subsection{Spectral analysis methods}

After calculating the spectral indices, all wavelengths of the measured spectral ranges (450 to $880 \mathrm{~nm}$ ) are evaluated. The aim of these spectral analysis methods is to show whether there is any difference 
in the wavelengths, given by the variation in humidity between treatments. In order to find these differences, correlation matrices are made between the wavelengths. Those wavelengths that have little variation between weeks and therefore high spectral correlation (variation given by different humidity conditions), will not provide relevant information to the regression models. On the contrary, wavelengths with low correlations are those that will provide more information to the models. Figure 5 illustrates the correlation process where the bands with less correlation are extracted because they contribute more information to the regression model.

In general terms, it can be seen from the matrices that the wavelengths in the visible region are highly correlated with each other, decreasing their correlation in the infrared lengths. Over the weeks, a decrease in the correlation becomes noticeable specifically in two ranges between 758-764 and 814-820. These two ranges with the greatest discrepancy are given by the variability between the treatments. When the analysis is carried out at the treatment level, the ranges with the greatest discrepancy coincide with the matrices carried out by week.

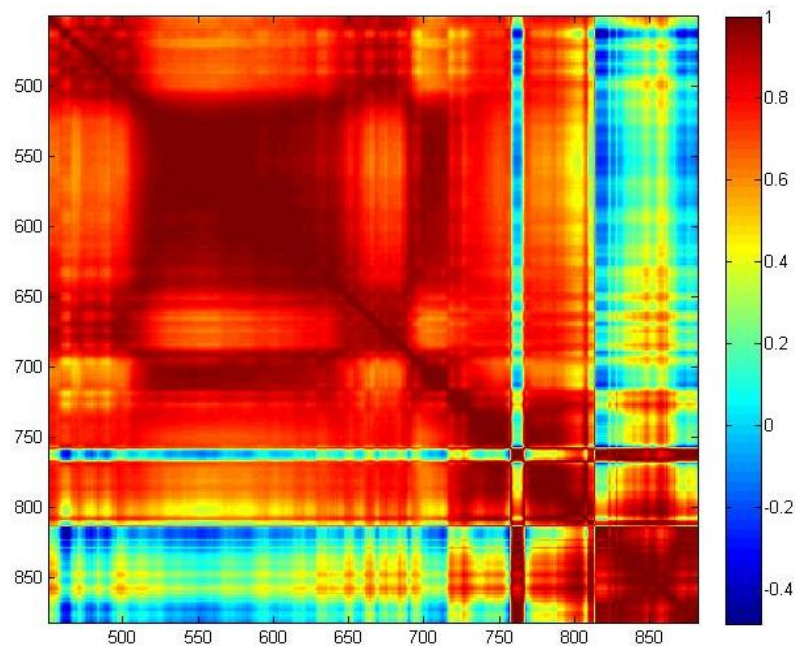

Figure 5. Correlation matrix for week 10 (as example), the red part of the image represents high correlation, so those bands do not have important information for the analysis, the bands in other colors represent low correlation so the information is more relevant

These spectral bands coincide with the wavelength values using the indices that have the highest correlation with the biophysical variable soil moisture. Therefore, it is assumed that these ranges are the ones that could give us the most input in a regression model. Since their variation is given by the differentiation of humidity in the treatments.

\subsection{Absorption analysis of spectral signatures}

In this study four absorption bands were selected, the first one was selected since it is the characteristic absorption of the spectral signature corresponding to vegetation given by the low reflectivity in red due to the absorbing effect of the chlorophyll pigments and the high reflectance in the near infrared where there is a low absorptivity of the chlorophylls and on the other hand to the internal cellular structure of the leaf where the internal air cavities in the leaf allow most of the incident radiation to be scattered in this spectrum band. This region is known as the edge network and is considered the turning point for comparisons between spectral curves of different plant species, considered as an indicator of plant stress and senescence [26, 27]. Three other bands were selected taking into account the correlation analyses performed. The wavelength ranges are illustrated in Figure 6 for the ranges 550 to $730 \mathrm{~nm}, 750$ to $760 \mathrm{~nm}, 789$ to $815 \mathrm{~nm}$ and 815 to $819 \mathrm{~nm}$.

Initially the absorptions were adjusted by dividing the individual spectra (initial values of reflectivity at each wavelength) by the continuum (continuous line between each range). Figure 7 shows the values of the calculated absorption characteristics for each treatment and week. These calculated values, corresponding to the absorption characteristics, were then correlated with biophysical variables such as soil moisture, chlorophyll, bulb temperature and leaf water content. The result of these correlations shows an average correlation (-0.53) between the absorption width (WID) in band 1 (550-730) and the humidity variable. The second most important average correlation $(-0.51)$ is between the variable temperature and the WID characteristic in band 4 (815-819). 


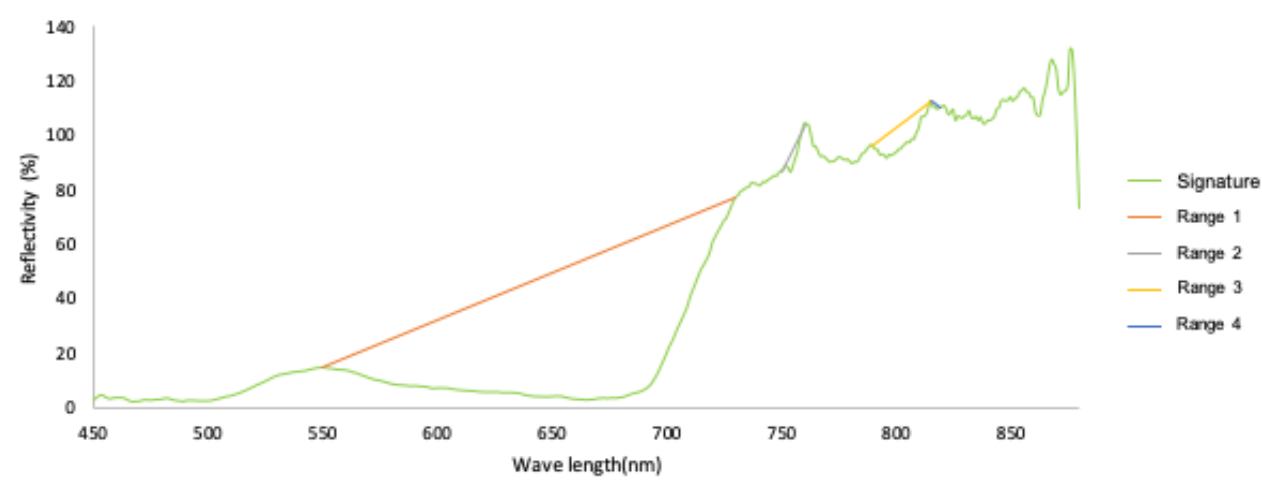

Figure 6. Determined ranges of analysis, the ranges have been marked with colored lines at the top of the spectral signature

\begin{tabular}{|c|c|c|c|c|c|c|c|c|c|c|c|c|}
\hline 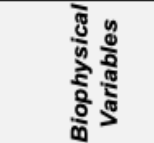 & 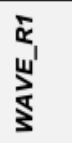 & 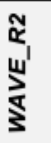 & 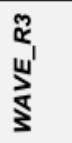 & 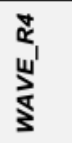 & 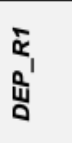 & $\begin{array}{l}\text { 品 } \\
\text { 岗 }\end{array}$ & 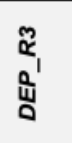 & 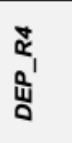 & $\begin{array}{l}\bar{\alpha}_{1} \\
q^{\prime} \\
\underline{s}\end{array}$ & 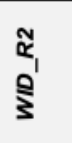 & $\begin{array}{l}\mathfrak{m}_{1} \\
\stackrel{1}{1} \\
\S\end{array}$ & 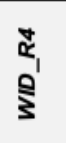 \\
\hline Humidity & $-0,30$ & & 0,26 & 0,11 & $-0,08$ & 0,28 & 0,43 & 0,12 & $-0,53$ & \begin{tabular}{|l|}
$-0,11$ \\
\end{tabular} & $-0,02$ & $-0,21$ \\
\hline Chlorophyll & 0,34 & & 0,15 & $-0,04$ & 0,14 & $-0,06$ & $-0,20$ & 0,01 & $-0,25$ & 0,11 & $-0,29$ & $-0,11$ \\
\hline Temperature & $-0,03$ & & 0,07 & 0,42 & $-0,13$ & $-0,04$ & $-0,20$ & $-0,41$ & $-0,17$ & $-0,37$ & $-0,07$ & $-0,51$ \\
\hline Water content & $-0,23$ & & $-0,17$ & 0,12 & 0,17 & $-0,14$ & $-0,30$ & $-0,27$ & 0,01 & $-0,27$ & 0,25 & $-0,30$ \\
\hline
\end{tabular}

Figure 7. Correlation matrix: absorption characteristics vs. biophysical variables

\subsection{Linear and non-linear regressions}

The regression analysis allowed us to show which wavelengths could provide the greatest contribution to the models. Taking into account the importance given by the model, the length with the greatest contribution was selected (869). Additionally, a correlation was made between the wavelengths for the weeks evaluated and the different treatments with the soil moisture values. Wavelength 869 is the value with the highest correlation as shown in Figure 8.

In order to reduce the number of wavelengths between the ranges generated by the analyses, a correlation matrix was made between these lengths and the humidity variable. From this matrix, wavelengths 764 and 815 were selected, wavelengths with the highest correlation. Initially, the relationship between wavelength values and soil moisture was evaluated. In treatment 1 (Saturation), no relationship is evident. In this evaluated timeline even this condition does not generate a stress that physiologically affects the palm and is represented in the spectral signature. For this reason, the following was not included in the model. For treatments 2 (Deficit) and 3 (Field capacity), 4 regression models were evaluated, 1 linear and 3 non-linear (Two phase decay, 2 and 3 order polynomial).

\begin{tabular}{|ccc|c|c|}
\cline { 5 - 5 } \multicolumn{1}{c}{} & \multicolumn{1}{c}{ L-764 } & L-815 & L-869 \\
\hline \multirow{2}{*}{ Linear } & R2 & 0,54 & 0,58 & 0,56 \\
& RMSE & 4,12 & 3,96 & 4,04 \\
\hline \multirow{2}{*}{ Two-phase decay } & R2 & 0,60 & 0,64 & 0,63 \\
& RMSE & 4,62 & 4,38 & 4,45 \\
\hline \multirow{2}{*}{ Polynomial 3 orden } & R2 & 0,70 & 0,73 & 0,71 \\
& RMSE & 3,75 & 3,56 & 3,66 \\
Polynomial 2 orden & R2 & 0,61 & 0,65 & 0,63 \\
& RMSE & 4,03 & 3,82 & 3,89 \\
\hline
\end{tabular}

Figure 8. Linear and non-linear regression models evaluated 
As can be seen, in all the models evaluated, wavelength 815 has the highest determination coefficients and the lowest RMSE. At this wavelength, the regression model that had the best fit was the 3rd order polynomial. In (1) the equation of the proposed model is presented.

$$
2.275 .21-56.05 X+0.46 X^{2}-0.001 X^{3}
$$

where $\mathrm{X}$ is the value of reflectivity at wavelength 815 . To validate the regression model, $20 \%$ of the field information was used. The estimated moisture values are adjusted to the actual values with deviations of less than $15 \%$ for treatments and standard deviations inferred from 2.2.

\section{CONCLUSION}

Spectroscopy allows differentiation of biophysical variables related to plant stress conditions such as soil moisture, bulb temperature, chlorophyll and leaf water content. It is expected that these correlations will increase as the effect of stress is prolonged for this type of crop, since the African palm is a crop that can resist prolonged periods of drought by means of some physiological mechanism that allows the regulation of the water level in its tissues. Some studies have shown that the palm has an efficient use of its stomas, which close avoiding water loss, maintaining the water content of its tissues, which increases its resistance to water phenomena. The mathematical model built that had the greatest adjustment for treatments 2 and 3 in the estimation of soil moisture content was the third order polynomial model with an $R^{2}=0.73$. This will allow the farmer with the use of remote sensors that generate spectral images with the wavelength $815 \mathrm{~nm}$ to diagnose water stress problems early at low cost and with good reliability.

\section{ACKNOWLEDGEMENTS}

This work was supported by the Universidad Católica de Manizales with the research groups on Technological and Environmental Development GIDTA and the program Master in Remote Sensing. The authors want to tank to "Manuelita Aceites y Energía" and "Corporación Colombiana de Investigación Agropecuaria-AGROSAVIA" for its support in this study.

\section{REFERENCES}

[1] X. Yu, H. Luo, H. Wang, J.-H. Feil, "Climate change and agricultural trade in central Asia: evidence from Kazakhstan," Ecosystem Health and Sustainability, vol. 6, no. 1, p. 1766380, 2020.

[2] K. T. Thinda, et al., "Understanding the adoption of climate change adaptation strategies among smallholder farmers: Evidence from land reform beneficiaries in South Africa," Land Use Policy, vol. 99, p. 104858, 2020.

[3] M. Dimyati, K. Kustiyo and R. D. Dimyati, "Paddy field classification with MODIS-terra multi-temporal image transformation using phenological approach in Java Island," International Journal of Electrical and Computer Engineering (IJECE), vol. 9, no. 2, pp. 1346-1358, 2019.

[4] W. N. Y. M. Desa, A. Fudholi and Z. Yaakob, "Energy-economic-environmental analysis of solar drying system: a review," International Journal of Power Electronics and Drive Systems (IJPEDS), vol. 11, no. 2, pp. 1011-1018, 2020.

[5] M. Agovino, M. Casaccia, M. Ciommi, M. Ferrara, K. Marchesano, "Agriculture, climate change and sustainability: The case of EU-28," Ecological Indicators, vol. 105, pp. 525-543, 2019.

[6] F. Prada, I. M. Ayala-Diaz, W. Delgado, R. Ruiz-Romero, H. M. Romero, "Effect of fruit ripening on content and chemical composition of oil from three oil palm cultivars (Elaeis guineensis Jacq.) grown in Colombia," Journal of Agricultural and Food Chemisty, vol. 59, no. 18, pp. 10136-10142, 2011.

[7] J. C. Acevedo, J. A. Hernández, C. F. Valdés, S. K. Khanal, "Analysis of operating costs for producing biodiesel from palm oil at pilot-scale in Colombia," Bioresource Technology, vol. 188, pp. 117-123, 2015.

[8] J. U. Devkota, "Statistical analysis of night radiance RH using VIIRS day/night band satellite time series data," International Journal of Advances in Applied Sciences (IJAAS), vol. 8, no. 1, pp. 26-33, 2019.

[9] B. C. Naik and B. Anuradha, "Extraction of Water-body Area from High-resolution Landsat Imagery," International Journal of Electrical and Computer Engineering (IJECE), vol. 8, no. 6, pp. 4111-4119, 2018

[10] N. T. Tam, H. T. Dat, P. M. Tam, V. T. Trinh, N. T. Hung, Q. -T. Huynh, J. Jo, "Monitoring agriculture areas with satellite images and deep learning," Applied Soft Computing, vol. 95, p. 106565, 2020.

[11] J. Pirker, A. Mosnier, F. Kraxner, P. Havl'ik, M. Obersteiner, "What are the limits to oil palm expansion?," Global Environmental Change, vol. 40, pp. 73-81, 2016.

[12] F. Colombia, "Acto de suscripción de la Declaración Conjunta de Compromiso por el Aceite de Palma Sostenible de Colombia," Revista Palmas. Bogotá (Colombia), vol. 40, no. 2, pp. 63-64, 2019.

[13] M. N. A. M. Yusoff, et al., "Sustainability of Palm Biodiesel in Transportation: a Review on Biofuel Standard, Policy and International Collaboration between Malaysia and Colombia," BioEnergy Research, pp. 1-18, 2020.

[14] P. R. Furumo, X. Rueda, J. S. Rodríguez, I. K. P. Ramos, "Field evidence for positive certification outcomes on oil palm smallholder management practices in Colombia," Journal of Cleaner Production, vol. 245, p. 118891, 2020. 
[15] H. Quesada, "Cultivo e industria de la palma aceitera (Elaeis guineensis)," 2001. [Online]. Available: https://propalma.webcindario.com/cultvopalma.htm.

[16] J. Fry, "Competitividad global del aceite de palma," Revista Palmas, vol. 31 pp. 35-43, 2010.

[17] T. Fairhurst, et al., "Palma de aceite Manejo para rendimientos altos y sostenibles," 2012. [Online]. Available: http://web.fedepalma.org/sites/default/files/files/Fedepalma/palmas_tomoI.pdf.

[18] L. S. Jurid, S. I. Zubairi, Z. M. Kasim, I. A. Ab Kadir, "The effect of repetitive frying on physicochemical properties of refined, bleached and deodorized Malaysian tenera palm olein during deep-fat frying," Arabian Journal of Chemistry, vol. 13, no. 7, pp. 6149-6160, 2020.

[19] T. S. Najihah, et al., "Activity of the oil palm seedlings exposed to a different rate of potassium fertilizer under water stress condition," AIMS Environmental Science, vol. 7, no. 1, pp. 46-68, 2020

[20] R. Pu, S. Ge, N. M. Kelly, P. Gong, "Spectral absorption features as indicators of water status in coast live oak (Quercus agrifolia) leaves," International Journal of Remote Sensing, vol. 24, no. 9, pp. 1799-1810, 2003.

[21] D. Fenández Arango, M. P. Martín, P. del Hoyo, J. Pacheco-Labrador, "Estimación del contenido de humedad de la vegetacion herbácea en una zona de dehesa a partir de imágenes hiperespectrales adquiridas por el sensor aeroportado CASI," 2015. [Online]. Available: http://www.geofocus.org/index.php/geofocus/article/view/399.

[22] M. E. Herrera and E. C. Salinero, "Estimación del contenido de agua a partir de mediciones hiperespectrales para cartografía del riesgo de incendio," Cuadernos de Investigación Geográfica, vol. 40, no. 2, pp. 295-309, 2014.

[23] S. O. Ihuoma and C. A. Madramootoo, "Crop reflectance indices for mapping water stress in greenhouse grown bell pepper," Agricultural Water Management, vol. 219, pp. 49-58, 2019.

[24] S. O. Ihuoma and C. A. Madramootoo, "Sensitivity of spectral vegetation indices for monitoring water stress in tomato plants," Computers and Electronics in Agriculture, vol. 163, p. 104860, 2019

[25] L. Araque and A. Jiménez, "Caracterización de firma espectral a partir de sensores remotos para el manejo de sanidad vegetal en el cultivo de palma de aceite," Revista Palmas, vol. 30, no. 3, pp. 63-79, 2009.

[26] Y. B. López and Y. Betzaida, "Metodología para identificar cultivos de coca mediante análisis de parámetros red edge y espectroscopia de imágenes," Tesis, Universidad Nacional de Colombia, Bogotá, 2012.

\section{BIOGRAPHIES OF AUTHORS}

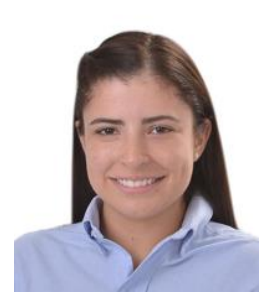

Angie Marcela Galvez Valencia Agricultural engineer, Master in remote sensing. Currently working as a field engineer at Manuelita Aceites y Energía, accompanying the use of technologies and the development of agricultural tools that allow monitoring of agronomic variables. E-mail: angie.galvez@manuelita.com.

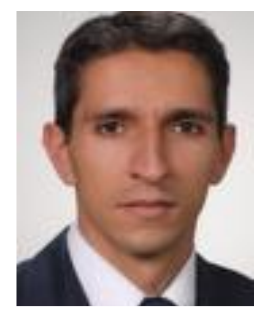

Yeison Alberto Garces-Gómez Electrical Engineer, M.Sc. (Eng) Industrial Automation, Ph.D. on Engineering. Associated Professor, UAFCNM, Universidad Católica de Manizales, Manizales, Colombia. E-mail: ygarces@ucm.edu.co. His research interests include power definitions under no sinusoidal conditions, power quality analysis, and power electronic applications. He is member of the Research Group on Technological and Environmental Development GIDTA and Education and Educators Training EFE. http://orcid.org/0000-00029409-3652

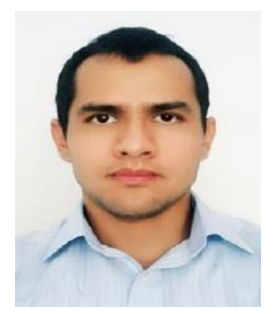

Erwin Leandro Lemus Rodriguez Agronomist, specialist with a postgraduate degree in senior management, working as founder of specialized processes in field technical control, head of agricultural research and development in oil palm cultivation and currently head of technical assistance of fruit suppliers for the group Manuelita, in the Manuelita Aceites y Energia business unit. E-mail: erwin.lemus@manuelita.com

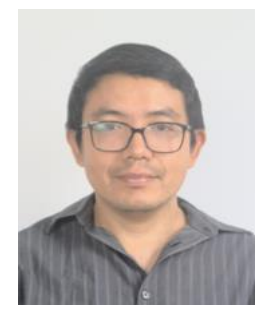

Miguel Andres Arango Argoti B.S in Agronomy, M.S and $\mathrm{PhD}$ in Soil and environmental sciences. Soil Scientist at the Colombian Corporation for Agricultural Research (AGROSAVIA) His research has been focused on climate change topics related to agriculture, mainly understanding the interaction between environmental factors and productivity. E-mail: marangoa@agrosavia.co. https://orcid.org/0000-0002-1041-072X 